\title{
Recent Articles in Ageing Research
}

\section{List No. 3, collected September, 1971-March, 1972}

As a regular feature of Gerontologia, the Editors publish in each issue a selection of recent articles in all fields of ageing research covered by this journal, appearing in other journals in this field and in some multi-disciplinary journals generally accessible to most readers. This selection does not intend to be complete, but to present articles which in the opinion of the Editors will be of interest to our readers. The Editors are responsible for the selection, but invite readers to bring to their attention articles which they think should be included in the next list.

General

Mateev, D.: Biologische Grundlagen des Alterns aus der Sicht des Physiologen. Z. Alternsforsch. 24: 117-126 (1971).

Mateeff, D.: Biological basis of aging. Agressologie 12: 75-86 (1971).

Rotzsch, W.; Beiër, W.; Leutert, G. und Ries, W.: Zur Molekularbiologie des Alterns.

3.Mitteilung: Das Altern aus der Sicht der experimentellen Gerontologie. Z. Alternsforsch. 24:

127-132(1971).

Verzár, F.: Physiologic und Gerontologie. Z.Alternsforsch. 24: 209-213 (1971).

Biochemistry

Comolli, R.: NADPH and ascorbate catalyzed peroxydation of microsomal lipids during ageing. Experientia 27: 1166-1167(1971). Everitt, A. V. and Delbridge, L.: Two phases of collagen ageing in the tail tendon

of hypophysectomized rats. Exp.Geront. 7: 45-52 (1972). Finch, C. E.: Enzyme activities, gene function and ageing in mammals (review). Exp.

Geront. 7: 52-68 (1972). Harzer, K. and Sundhoff, K.: Age-dependent variations of the human N-acetyl-/?-D-

hexosaminidases. J.Neurochem. 18: 2041-2050 (1971). Hellthaler, G.; Köhler, H. und Rotzsch, W.: Alternsabhängige Veränderungen der

Proteinsynthese von Dünndarmringen. Z. Alternsforsch. 24: 2A\%o2AI (1971). Huemer, R.P.;

Lee, K.D.; Reeves, A. E., and Bickert, C: Mitochondrial studies in

senescent mice. II. Specific activity, buoyant density, and turnover of mitochondrial

DNA. Exp.Geront. 6: 327-334 (1971). Klimenko, A. I.: Age features in the content of RNA,

DNA and protein in cell nuclei

of rat liver during induction with hydrocortisone. Vop. med. Khim. 17: 615-618 (1971). Mason,

R. M.: Observations on the glycosaminoglycans of aging bronchial cartilage

studied with alcian blue. Histochem. J. 3: 421-434 (1971). Mishra, B. N.; Sahu, N., and Patnaik,

B. K.: Age-related changes in the $\mathrm{Ca} / \mathrm{P}$ molar

ratio in the bones of the garden lizard, Calotes versicolor. Exp.Geront. 6: 309-312

(1971). Paik, W. K.; Lee, H. W., and Lawson, D.: Age-dependency of various protein me-

thylases. Exp.Geront. 6: 271-278 (1971). Platt, D. and Pauli, H.: Age-dependant determinations of lysosomal enzymes in the

liver of spironolactone and aldosterone pretreated rats. Exp.Geront. 7: 1-8 (1972). 
340

Recent Articles in Ageing Research

Rao, K. L. and Patnaik, B. K.: Effect of age and hepatectomy on the glycogen content of liver of the garden lizard, Calotes versicolor. Exp.Geront. 6: 287-292 (1971). Rao, K. L. and Patnaik, B. K.: Alterations in the RNA, protein and free amino acid

level of the liver of the garden lizard, Calotes versicolor, during aging and partial hepatectomy. Exp.Geront. 6: 397-404 (1971). Rao, K. L. and Patnaik, B. K.: Change in lipid content of the liver of Calotes versicolor

during aging and partial hepatectomy. Exp.Geront. 7: 69-71 (1972). Rosenberg, B.; Kemeny, G.: Switzer, R. C, and Hamilton, T. C: Quantitative

evidence for protein denaturation as the cause of thermal death. Nature, Lond. 232:

471-473 (1971). Saladino, C. F.; Beitz, D. C, and Getty, R.: RNA/protein ratios of canine pancreatic

microsomes and their subfractions as a function of age. Exp.Geront. 6: 359-366 (1971). Salser, J. S. and Balis, M. E.: Alterations in DNA-bound amino-acids with age and sex. J.Geront. 27: 1-9 (1972). Schmeir, M. and Buch, L.: The unlikelihood that malonaldehyde arising from in vivo

lipid degradation contributes to collagen crosslinking. J.Geront. 27: 22-24 (1972). Shirey, T. L. and Sobel, H.: Compositional and transcriptional properties of chromatins isolated from cardiac muscle of young-mature and old dogs. Exp.Geront. 7: 15-30

(1972). Sun, G.Y. and Samorajski, T.: Age changes in the lipid composition of whole homogenates and isolated myelin fractions of mouse brain. J.Geront. 27: 10-17 (1972). Winter, D.; Dobre, V., and Oeriu, S.: Cysteine-S35 absorption in old rats. Exp.Geront.

6: 367-372 (1971).

Histology, Cytology, Comparative Anatomy

Chatterji, S.; Wall, J. C, and Jeffery, J.W.: Changes in the degree of orientation

of bone materials with age in the human femur. Experientia 28: 156-157 (1972). Hillman, R.W.;

Smith, H. S., and Levine, J. S.: Cytoplasmic granules in buccal cells:

an age-related phenomenon? J. Geront. 27: 18-21 (1972). Lagier, R.: Anatomo-pathologie du vieillissement osteo-articulaire. Lyon méd. 226:

737-754 (1971). Nanda, B. S. and Getty, R.: Lipofuscin pigment in the nervous system of the ageing

pig. Exp.Geront. 6:447-452 (1971). Nanda, B. S. and Getty, R.: Age-related histomorphological changes in the cerebral

arteries of the domestic pig. Exp.Geront. 6: 453-460 (1971). Pauli, B. and Luginbühl, H.:

Fluorescence microscopical observations of cerebral

amyloidosis in aged dogs and senile humans. Acta neuropath. 19: 121-128 (1971). Pauli, B.;

Luginbühl, H., and Rossi, G. L.: Electron microscopical studies of cerebral

amyloidosis in aged dogs and a senile human. Acta neuropath. 19: 129-136 (1971). Paulini, K.;

Beneke, G. und Kulka, R.: Zytophotometrische und autoradiographische

Untersuchungen zur Lebervergrösserung nach Phenobarbital in Abhängigkeit vom

Lebensalter. Beitr. Pathol. 144: 319-326 (1971). Rodman, T. C: Chromatid disjunction in

unfertilized ageing oocytes. Nature, Lond.

233: 191-192 (1971). Samorajski, T.; Friede, R. L., and Ordy, J. M.: Age differences in the ultrastructure

of axons in the pyramidal tract of the mouse. J.Geront. 26: 542-551 (1971). 
Recent Articles in Ageing Research

341

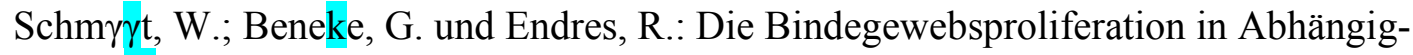

keit vom Lebensalter. III. Zytophotometrische Untersuchungen. Beitr. Pathol. 144:

272-280 (1971). Sohal, R. S. and Allison, V. F.: Senescent changes in the cardiac myofiber of the house

fly, Musca domestica. J.Geront. 26: 490-496 (1971). Weisse, I.; Knappen, F.; Schrank, H. und Klupp, H.: Das Blutbild der englischeo

Beagle-Hunde in Abhängigkeit von Alter und Geschlecht. Arzneimittelforsch. 21:

1703-1706 (1971).

Immunology

Chino, F.; Makinodan, T.; Lever, W. E., and Peterson, W. J.: The immune system of mice reared in clean and dirty conventional laboratory farms. I. Life expectancy and pathology of mice with long life-spans. J.Geront. 26: 497-507 (1971).

Makinodan, T.; Chino, F.; Lever, W. E., and Brewer, B. S.: The immune system of mice reared in clean and dirty conventional laboratory farms. II. Primary antibody-forming activity of young and old mice with long lifespans. J.Geront. 26: 508-514 (1971).

Makinodan, T.; Chino, F.; Lever, W. E., and Brewer, B. S.: The immune system of mice reared in clean and dirty conventional laboratory farms. III. Ability of old mice to be sensitized to undergo a secondary antibody response. J.Geront. 26: 515-520 (1971).

Strausser, H. R.; Bober, L. A.; Bucsi, R. A.; Shillcock, J. A., and Goldstein, A.L.: Stimulation of the hemagglutinin response of aged mice by cell-free lymphoid tissue fractions and bacterial endotoxin. Exp.Geront. 6: 367-372 (1971).

Longevity, Population Genetics

Berberian, P. A.; Rockstein, M., and Gray, F. H.: The effect of egg laying on the longevity of the adult housefly, Musca domestica. J. Geront. 26: 485-^89 (1971). EgaMI, N.: Further notes on the lifespan of the teleost, Oryzias latipes. Exp. Geront. 6:

379 (1971). Harman, D.: Free radical theory of aging: effect of the amount and degree of unsaturation

of dietary fat on mortality rate. J.Geront. 26: 451-457 (1971). Leonard, A.; Deknudt, G., and Mattelin, G.: Study of the lifespan of a strain of

cataractous rats. Exp.Geront. 6: 293-296 (1971). Lints, F. A. and Lints, C. V.: Influence of preimaginal environment on fecundity and

ageing in Drosophila melanogaster hybrids. II. Prcimaginal temperature. Exp. Geront.

6: 417-426 (1971). Lints, F. A. and Lints, C. V.: Influence of pre-imaginal environment on fecundity and

ageing in Drosophila melanogaster hybrids. III. Developmental speed and life-span.

Exp.Geront. 6: 427-446 (1971). Seber, G. A. F.: Estimating age-specific survival rates from birdband returns when the

reporting rate is constant. Biometrika 58: 491-498 (1971). Yuhas, J. M.: Age and susceptibility to reduction in life expectancy: an analysis of

proposed mechanisms. Exp.Geront. 6: 335-344 (1971).

Metabolism

Ber, A. and Allalouf, D.: The pattern of urinary glycosaminoglycan excretion in relation to age in man. J.Geront. 27: 28-32 (1972).

342 
Recent Articles in Ageing Research

Bruhis, S.; Moldoveanu, E.; Klein, R.; Dumitraßc, N., and Oeriu, S.: Age-relations

of cellular growth inhibitors of ketoaldehyde type, in liver and brain of rat. Exp.

Geront. 7: 9-14 (1972). Deyl, Z.; Rosmus, J., and Adam, M.: Hormonal control of collagen ageing. Exp. Geront.

7: 11-M, (1972). Deyl, Z.; Juricová, M.; Rosmus, J., and Adam, M.: The effect of food

deprivation

on collagen accumulation. Exp. Geront. 6: 383-390 (1971). Fujita, T.; Okano, K.; Orimo, H.;

Ohata, M., and Yoshikawa, M.: Age and fate

of parathyroid hormone. J. Geront. 27: 25-27 (1972). McGeer, E. G.; Fibiger, H. C.; McGeer, P.

L., and Wickson, V.: Aging and brain

enzymes. Exp. Geront. 6: 391-396 (1971). Sobel, H.: Calcium metabolism in aging mice. J.

Geront. 26: 552-554 (1971). Sobel, H.: Metabolism of hyaluronic acid in the skin of aging mice.

J. Geront. 26: 555-

557 (1971). Sobel, H. and Bowman, R.: Protein metabolism in aging mice. J. Geront. 26: 558

(1971). Sobel, H. and Bowman, R.: Is protein catabolism nonrandom? Experientia 27: 1163

(1971). Stuchlíková, E.; JelínkovA, M., and Smrz, M.: The digestibility of subcutaneous

adipose tissue from women of different ages. Exp. Geront. 6: 305-308 (1971). Stuchlíková, E.;

Jelínková, M.; Faltová, E., and Smrz, M.: Age-dependent lipo-

lytic activity of the rat myocardium in relation to its triglyceride content. Possible

new factor in ischaemic heart disease? Exp. Geront. 6: 297-304 (1971). Tonna, E. A.: An

autoradiographic study of $3 \mathrm{H}$-proline utilization by aging mouse

skeletal tissues. II. Cartilage cell compartments. Exp. Geront. 6: 405^416 (1971).

Pharmacology

Hajdu, A. and Rona, G.: The protective effect of estrogens against spontaneous pancreatic islet and renal changes in aging male rats. Experientia 27: 956-957 (1971).

Physiology and Cell Biology

Das, L. N. and Magilton, J. H.: Age changes in the relationship among endocrine glands of the beagle. Exp. Geront. 6: 313 (1971). Das, B. C. and Sharma, J. S.: Linked crosssectional study of age-related changes in

human blood chemistry, haematology and circulatiory function. Exp. Geront. 6: 345-

358 (1971). Herman, M. M.; Miquel, J., and Johnson, M.: Insect brain as a model for the study of aging. Age-related changes in Drosophila melanogaster. Acta neuropath. 19: 167-

183 (1971). Muggleton-Harris, A. L.: Cellular events concerning the developmental potentiality of the transplanted nucleus, with reference to the aging lens cell. Exp. Geront. 6: 279-

286 (1971). Muggleton-Harris, A. L.: Ageing factors affecting the ability of adult lens cell nuclei for cleavage and development. Exp. Geront. 6: $461-468$ (1971). Nikaido, T.; Austin, J.; Rinehart, R.; Trueb, L.; Hutchinson, J.; Stukenbrok, H.,

and Miles, B.: Studies in ageing of the brain. Arch.Neurol., Chicago 25: 198-211

(1971).

Recent Articles in Ageing Research

343

Tomanek, R. J.; Taunton, C. A., and Liskop, K. S.: Relationship between age, chronic exercise and connective tissue of the heart. J.Geront. 27: 33-38 (1972).

Ueno, Y.: Radiosensitivities of the hemopoietic system in young and old mice. Exp. Geront. 6: 469 (1971). 


\section{Plants}

Anker, P.; Stroun, M.; Greppin, H., and Fredj, M.: Metabolic DNA in spinach stems in connexion with ageing. Nature New Biology 234: 184-185 (1971). Mishra, S. D. and Gaur, B. K.: Control of senescence in betel leaves by depetiolation.

Exp. Geront. 7: 31-36 (1972).

Psychology and Behaviour

Botwinick, J.: Sensory-set factors in age-differences in reaction time. J. genet. Psychol.

119: 241-250 (1971). Freund, G. and Walker, D.W.: The effect of ageing on acquisition and retention of

shuttle box avoidance in mice. Life Sci., Part 1,10: 1343-1350 (1971). 